\title{
Controlling of bacterial and fungal diseases that contaminating mulberry silkworm, Bombyx mori by using some plant extracts
}

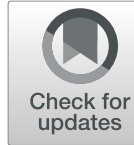

\author{
Mahmoud S. I. Saad ${ }^{1 *}$ (D, Enas M. Y. Elyamani ${ }^{1}$ and Walaa M. M. Helaly ${ }^{2}$
}

\begin{abstract}
Background: Mulberry silkworm, Bombyx mori L. is one of the most economically important insect because its production of silk which interfere with many important industries. Diseases of the silkworm, B. mori such as viral, bacterial, fungal and protozoan pathogens seriously affect their cocoon production. Bacterial and fungal pathogens independently cause the highest cocoon loss, so the use of botanicals is considered an important strategy to control diseases of silkworm.

Results: The artificially infected silkworm, B. mori larvae with Bacillus thuriengiensis when treated with concentrations of 2 and $3 \%$ of black seed and basil leaves extracts increased significantly larval weight and decreased larval mortality. In addition, 3\% basil leaves extract and 1\% of black seed increased pupal weight. Cocoon weight and cocoon shell weight increased significantly by $3 \%$ basil leaves extract treatment. All tested concentrations of black seed extract increased the silk ratios of the resulted cocoons as compared to the infected control. For technological parameters, all tested extracts at 3\% concentration caused the highest silk filament length; meanwhile control larvae recorded the highest silk filament weight and size. Regarding the mulberry silkworm, B. mori artificially infested with conidial solution of Beauveria bassiana when treated with all concentrations of the tested plants showed an enhancement in larval weight, pupal weight, cocoon weight, cocoon shell weight, silk filament length, and filament weight and reduced the larval mortality percentage. The highest silk filament size were recorded for the control group.

Conclusions: Tested concentrations of Morus alba, Ocimum basilicum leaves extracts and Nigella sativa seeds extract have suppressed the bacterial and fungal disease spread when used three times through both 4th and 5th larval instars. Moreover, the biological characters and technological traits enhanced by using of these extracts, so it can be used in sericulture for improving cocoon crop quality and quantity.
\end{abstract}

Keywords: Bombyx mori, Bacillus thuriengiensis, Beauveria bassiana, Artificially infection, Biology, Technology, Silk filament

\section{Background}

Natural silk is produced by the silkworm, which is used for many purposes. Silk thread has several uses, including parachute manufacturing, tire lining, electrical insulation, artificial blood vessels, surgical thread. Oil can be extracted from silkworm pupa, amino acids and vitamin B2 and can be used in the pharmaceutical industry. Phytol, an important raw material to make vitamin $\mathrm{E}$ and $\mathrm{K}$, and colorful can be extracted from the faces of

\footnotetext{
*Correspondence: mshsaad@gmail.com

'Plant Protection Research Institute, Agricultural Research Center, Dokkii 12622, Egypt

Full list of author information is available at the end of the article
}

the silkworm. The faces can also used to make activated carbon and acid-resistant plastic sheets, rich in protein, the silkworm faces are good feeds for fish, pigs, cattle and sheep. It is super organic manure (Souad Mahmoud (2016).

Overall, the silkworm industry plays an important and active role in the development of national income and stimulates the rural economy and the overall development of agriculture, forestry, animal husbandry, side-line occupations and fisheries, suprs the development of local light industry and expands trade (Dandin 2014).

The mulberry silkworm, B. mori produces silk, which are influenced by many pathogens includes fungi, 
bacteria, virus and protozoan which cause damages to cocoons reached to 75\% (Das 1950). The frequency of infections at silkworm breeding extremely diminishes the producing of silk. Microbes such as Streptococcus faccalis, Streptococcus liquifacions, Staphylococcus acire, Staphylococcus epidermidis and Bacillus sp. are commonly detailed to cause the bacterial flacherie in silkworm (Karthikairaj et al. 2013). The misfortunes happen basically amid the ultimate stages of silkworm raising coming about impressive vitality and cash loss.

The biodiversity of plants gives a potential source of the antimicrobial agents (Bushra and Ganga 2003), which may be applied for antiviral, antibacterial and antifungal effectiveness (Pereira et al. 2004; Kartal 2007). Morus alba L., known as white mulberry, has a shortlived, fast-growing, little to the medium tree. The last studies appeared $M$. alba has antioxidant, antibacterial, antiviral and anti-inflammatory properties (El-Beshbishy et al. 2006). Some phenolic compounds flavonoids, stilbenes, and 2-arylbenzofurans have been detailed from M. alba and have been known as antimicrobial (Yogisha and Raveesha 2009). M. alba has been distinguished as a multifunctional flexible plant with colossal dietary and wellbeing possibilities. The antimicrobial movement of the ethanolic and water extricates of $M$. alba variations appeared a few inhibitory control against the organisms like Pseudomonas aeruginosa, Neisseria gonorrheae and Proteus vulgaricus, Staphylococcus aureus and Streptococcus faecium for gram negative and gram positive microscopic organisms and against Asperguillus tamari, Asperguillus niger, Fusarium oxysporum and Penicillum oxalicum for organisms (Omidiran et al. 2012).

In spite of the fact that dark seed extract or oil has been detailed to have antimicrobial validity (Morsi 2000). Nigella sativa have pharmacological activities was investigated as anticancer, antimicrobial, anti-inflammatory, hepatoprotective, renal defensive, gastroprotective, antioxidant properties Desai et al. (2015). Numerous dynamic compounds have been separated and distinguished from dark seeds (Ahmed et al. 2013). These compounds were thymoquinone (30\%-48\%), thymohydroquinone, dithymoquinone, p-cymene $(7 \%-15 \%)$, carvacrol $(6 \%-12 \%)$, 4-terpineol $(2 \%-7 \%)$, t-anethol $(1 \%-4 \%)$, sesquiterpenelongifolene $(1 \%-8 \%) \alpha$-pineneand thymol etc.

Sweet basil (Ocimum basilicum L.) belongs to the family Lamiaceae, its constituents have antibacterial, antifungal, antioxidant and radio protective activity (Kath and Gupta 2006; Ramesh and Satkopan 2010). Prasad et al. (2012) indicate that, Осimum possesses compounds with antimicrobial properties against pathogenic microorganisms. O. sanctum extract has growth promoting effect on silkworm, which helps to enhance the commercial qualities of silk and can be used in sericulture for yield improvement.

\section{Aim of work}

The present study was carried out to evaluate the effect of some plant extracts to controlling bacterial and fungal diseases of mulberry silkworm $B$. mori larvae and their impact on some biological and technological aspects.

\section{Material and methods \\ Rearing of mulberry silkworm}

Silkworm eggs of commercial Bulgarian hybrid were used $(\mathrm{H} 1 * \mathrm{KK} * \mathrm{G} 2 * \mathrm{~V} 2)$ and obtained from Sericulture Research Department of Plant Protection Research Institute, Agricultural Research Center (ARC) and maintained in rearing room of silkworm under laboratory conditions $\left(28 \pm 2{ }^{\circ} \mathrm{C}\right.$ and $\left.70 \pm 5 \% \mathrm{RH}\right)$ according to the method described by Krishnaswami (1978). Mulberry leaves (Balady variety) were collected twice daily i.e. at 8 am and $4 \mathrm{pm}$, then washed and left to dry as needed in the room temperature. Rearing trays, tools, and rearing room were disinfected one-week prior the onset of the experiment using formalin 3\% (37-40\% formaldehyde). Larvae were offered to mulberry leaves 4 times/day in plastic trays $(42 \times 30 \times 10 \mathrm{~cm})$ with approximate number of 100 larvae/tray for three replicates for each concentration. The larval bed was cleaned daily using cleaning net for removing the remained dried food and feces. Chicken egg cartons plates were used as montages for cocoon spinning (Zannoon and Shadia 1994).

\section{Plant species and preparation of plant extracts}

The fresh leaves of mulberry leaves (Morus alba) and Basil leaves (Ocimum basilicum) were collected from mulberry trees and basil plant, and washed with tap water to remove soil and unwanted dust particles, then the leaves were air dried and then powdered by using mechanical blender and stored in air tight bottles. The Nigella sativa seeds were bought from a local herbal market, then powdered and stored as mentioned before. The extracts were prepared by soaking the plant powders in petroleum-ether for 4 days, then the petroleum-ether extracts were filtered by using filter papers. A rotary evaporator apparatus was used to remove the solvent, and the remaining extracts were stored in dark bottles in the refrigerator until use (Harborne 1984).

\section{Isolation of bacteria}

Bacterial isolation and identification was carried out in Agricultural Microbiology Department, ARC, Egypt. Bacterial pathogens were collected from black thorax Septicemia diseased larvae, the diseased larvae were crushed by using mortar and pestle. The homogenate was then filtered with silica filter. The filtrate was centrifuged at $5000 \mathrm{~g}$ for $10 \mathrm{~min}$. The supernatant was discarded, and the pellet was used for bacterial culture after re-suspending in distilled water (Aneja 2003). 
Preparation and count of bacterial culture

Bacillus thuringnsis were cultured over night in Nutrient agar medium at $28{ }^{\circ} \mathrm{C}$. Then, the bacterial colonies were selected and transferred into $10 \mathrm{ml} \mathrm{NaCl}$ (0.85\%) as stock solution. Cells were count in 100 ul using flow cytometry. The cell no. 50 cells the total cells in $1 \mathrm{ml}$ equal 500,000 cells. Serial dilution with different concentration bacterial spore suspension was made by take 900, 800, 700,600, 500,400,300, 200 and $100 \mu \mathrm{m}$ from stock solution and complete each one to $1 \mathrm{ml}$ by saline and take 1 $\mathrm{ml}$ from stock solution for $100 \%$ for making the different concentrations $100 \%, 90 \%, 80 \%, 70 \%, 60 \%, 50 \%, 40 \%, 30 \%$, 20\% and 10\% (Cockerill et al. 2012).

\section{Fungal isolation and preparation}

The fungus was isolated from silkworm larva died from white muscardine using Sabouraud Dextrose Agar medium according to Meyling and Eilenberg (2006) and Meyling (2007). Culture of Beauveria bassiana was maintained on Potato Dextrose Agar slants and was subcultured in Petri dishes according to Linday (1962). The conidial concentration $\left(1 \times 10^{7}\right.$ conidia /ml $)$ was estimated using Neubarhemocytometer under a Leitz DialuX20EB microscope (400x magnifications) according to Yeo et al. (2003).

\section{Infecting of silkworm larvae with bacteria and Fungi}

After preparing bacterial spore suspension, B. mori artificially infected by spraying the mulberry leaves with concentration (50\%) of bacterial suspension (B. thuringnsis) one time in the 2nd day of the 4th instar larvae (Hassan 2015). As for the fungus infection, the larvae were immersed in the prepared fungus solution for $10 \mathrm{~s}$.

\section{Experimental design and larval treatment}

The newly exuviated fourth instar larvae were separated into 3 groups with 100 larvae/group. One group infected with bacterial spore suspension (50\%) of bacterial $B t$ by spraying mulberry leaves and larvae, second group immersed in the fungal spores solution, and the third one immersed in distilled water only (Normal control), Both the first and second groups were divided into four other groups, three of which were treated with the materials used as follows:

Treat.1, 2, 3 - sprayed with 3, 2 and 1\% M. alba leaves extract.

Treat.4, 5, 6- sprayed with 3, 2 and 1\% Nigella sativa seeds extract.

Treat.7, 8, 9 - sprayed with 3, 2 and 1\% Ocimum basilicum leaves extract.

The fourth one used as infested control. All concentrations were applied as bed disinfectant three times during each of 4th and 5th larval instars by spraying over the larvae and mulberry leaves an hour before morning meal.

\section{Developmental and technological measurements}

Different biological characteristics were measured such as, larval mortality (\%), larval weight, larval duration, pupal weight, Fresh cocoon weight, shell cocoon weight and cocoon silk ratio was calculated according to Tanaka (1964) formula:

$$
\text { Silk ratio }(\%)=\frac{\text { Weight of cocoon shell }(\mathrm{g})}{\text { Weight of fresh cocoon }(\mathrm{g})} \times 1000
$$

For technological measurements, five cocoons of each treatment were dried in an oven at $60^{\circ} \mathrm{C}$ for $8 \mathrm{~h}$ to be reeled individually (Shaaban 1997). The length of reeled silk filament was measured and weighed for each cocoon. The size of the reeled silk filament (denier) was estimated according to Tanaka (1964) formula:

$$
\text { Size }(\mathrm{dn})=\frac{\text { Weight of silk filament }(\mathrm{g})}{\text { Length of filament }(\mathrm{m})} \times 9000
$$

\section{Statistical analysis}

Statistical analysis was performed using analysis of variance (ANOVA), IBM Costat V.6.311 (2005) Software Means were compared using Duncan's test $(\leq 0.05)$ according to Snedecor and Cochran (1982).

\section{Results}

Biological parameters of silkworm larvae treated by some extracts as disinfectant to control artificially infected with B. thuriengiensis

As shown in (Table 1) analysis of data revealed that, the differences between means larval weights were highly significant. The highest larval weights recorded 4.084, 4.032, 4.059 and $4.036 \mathrm{~g}$ for infected larvae treated with the extracts of $2,3 \%$ basil leaves and 3, 2\% black seed as compared to $3.008 \mathrm{~g}$ for infected control larvae.

Treating infected larvae by $2,3 \%$ black seed and 3, 2\% basil leaves decreased the larval mortality to 10.00 , $12.00,12.00,12$ and 10\%, respectively compared to $26.00 \%$ mortality in infected control larvae, while the lowest death rate was recorded for the normal control. The differences between means in this parameter are highly significant. Regarding silkworm pupal weight, the highest means $(1.266 \mathrm{~g})$ was recorded for infected larvae fed on mulberry leaves treated with $3 \%$ basil leaves extract. The normal control gave a higher pupal weight than the most coefficients used treatment. Analysis of data revealed highly significant differences among the means of pupal weights (Table 1). 
Table 1 Effect of Mulberry leaves, Black seeds and Basil leaves extracts as disinfectants on some biological and cocoon characters of infected Silkworm, B. mori larvae with B. thuringiensis

\begin{tabular}{|c|c|c|c|c|c|c|c|}
\hline Extracts & Conc. $^{a}$ & Larval weight (g) & Larval Mortality \% & Pupal weight (g) & Cocoon weight (g) & Cocoon shell wt. (g) & Silk ratio $\%$ \\
\hline \multirow[t]{3}{*}{ Mulberry Leaves } & $3 \%$ & $3.736^{a}$ & $16.0^{\mathrm{a}}$ & 1.06 & $1.382^{a}$ & $0.318^{a}$ & $23.13^{\mathrm{a}}$ \\
\hline & $2 \%$ & $3.563^{\mathrm{a}}$ & $16.0^{\mathrm{a}}$ & 1.082 & $1.362^{\mathrm{a}}$ & $0.322^{a}$ & $23.57^{\mathrm{a}}$ \\
\hline & $1 \%$ & $3.785^{\mathrm{a}}$ & $16.0^{\mathrm{a}}$ & 1.036 & $1.408^{\mathrm{a}}$ & $0.288^{\mathrm{a}}$ & $23.53^{\mathrm{a}}$ \\
\hline \multirow[t]{3}{*}{ Black seed } & $3 \%$ & $4.059^{\mathrm{a}}$ & $12.0^{\mathrm{a}}$ & 1.092 & $1.336^{\mathrm{a}}$ & $0.342^{\mathrm{a}}$ & $25.56^{\mathrm{a}}$ \\
\hline & $2 \%$ & $4.036^{\mathrm{a}}$ & $10.0^{\mathrm{a}}$ & 1.052 & $1.394^{\mathrm{a}}$ & $0.338^{\mathrm{a}}$ & $24.26^{\mathrm{a}}$ \\
\hline & $1 \%$ & $3.75^{\mathrm{a}}$ & $12.66^{\mathrm{a}}$ & 1.156 & $1.404^{\mathrm{a}}$ & $0.342^{\mathrm{a}}$ & $24.42^{\mathrm{a}}$ \\
\hline \multirow[t]{3}{*}{ Basil Leaves } & $3 \%$ & $4.032^{\mathrm{a}}$ & $10.0^{\mathrm{a}}$ & 1.266 & $1.642^{\mathrm{a}}$ & $0.354^{\mathrm{a}}$ & $21.56^{\mathrm{a}}$ \\
\hline & $2 \%$ & $4.084^{\mathrm{a}}$ & $12.0^{\mathrm{a}}$ & 1.114 & $1.428^{\mathrm{a}}$ & $0.342^{\mathrm{a}}$ & $23.94^{\mathrm{a}}$ \\
\hline & $1 \%$ & $3.932^{\mathrm{a}}$ & $14.0^{\mathrm{a}}$ & 0.940 & $1.244^{\mathrm{a}}$ & $0.296^{\mathrm{a}}$ & $23.81^{\mathrm{a}}$ \\
\hline \multicolumn{2}{|c|}{ B. thuringiensis control } & $3.008^{\mathrm{a}}$ & $26.0^{\mathrm{a}}$ & 0.954 & $1.216^{\mathrm{a}}$ & $0.26^{\mathrm{a}}$ & $21.38^{\mathrm{a}}$ \\
\hline \multicolumn{2}{|l|}{ Control } & $3.769^{\mathrm{a}}$ & $0.66^{\mathrm{a}}$ & 1.116 & $1.348^{\mathrm{a}}$ & $0.332^{\mathrm{a}}$ & $24.66^{\mathrm{a}}$ \\
\hline \multicolumn{2}{|l|}{$\mathrm{F}$} & 11.435 & 40.141 & 3.114 & 15.606 & 2.888 & 1.878 \\
\hline \multicolumn{2}{|l|}{$\mathrm{LSD}_{0.05}$} & 0.254 & 3.064 & 0.143 & 0.076 & 0.048 & 3.43 \\
\hline \multicolumn{2}{|l|}{$P \geq 0.05$} & $0.000^{* *}$ & $0.000^{* *}$ & $.0031^{* *}$ & $0.000^{* *}$ & $0.0054 * *$ & $0.0665^{*}$ \\
\hline
\end{tabular}

${ }^{a}$ The tested concentrations of plant extracts (\%)

${ }^{*}, *$ denote significant and highly significant differences at $0.05,0.01$ levels of probability

\section{Cocoon characters}

Feeding silkworm, B. mori larvae on mulberry leaves treated with $3,2 \%$ basil leaves extract resulted in the highest cocoon weight recording 1.642 and $1.428 \mathrm{~g}$. On the other hand, treating silkworm, $B$. mori with infected mulberry leaves by bacterial suspension (B. thuringnsis) attained the least cocoon weight $1.216 \mathrm{~g}$ (Table 1). Other tested extract concentration showed intermediate values. Meanwhile, the normal control gave relatively high values for the weight of fresh cocoons. The differences of means revealed highly significant among concentrations in this parameter.

Statistical analysis of data revealed highly significant differences in cocoon shell weights among the concentrations. Data in (Table 1) indicated that, the highest cocoon shell weights recorded $0.354,0.342,0.342$ and $0.342 \mathrm{~g}$ for infected larvae fed on mulberry leaves treated with the extracts of $3,2 \%$ basil leaves and 3, $1 \%$ black seed, respectively. The normal control recorded relatively high values of $0.332 \mathrm{~g}$ in comparison with infested control which recorded $0.260 \mathrm{~g}$.

As shown in (Table 1), the maximum silk ratios were detected when infected larvae fed on mulberry leaves treated with 3, control, 2 and 1\% black seed extract recording, 25.56, 24.66, 24.26 and $24.42 \%$, respectively. On the contrary, the least silk ratio $21.38 \%$ was noticed with control-infected larvae without treatment. The differences between silk ratio means are significant.

\section{Silk filament characters}

Concerning silk filament length, all tested concentrations increased the silk filament length with highly significant differences between means (Table 2). The corresponding lowest silk filament length $775.35 \mathrm{~m}$ was recorded for infected control larvae. Moreover, the longest filament length was recorded 1271.50, 1226.50 and $1214.5 \mathrm{~m}$ for cocoons resulted from larvae treated by high concentration of mulberry leaves, basil leaves and black seeds, respectively.

Analysis of data revealed highly significant differences among the silk filament weight means (Table 2). The maximum value $0.318 \mathrm{~g}$ was noticed for control larvae. All tested treatments increased filament weights comparing with filament weights resulting from cocoons spun by larvae treated with infected mulberry leaves by bacterial suspension.

Data tabulated in Table 2 revealed highly significant differences between silk filament size means. The highest silk filament size $2.627 \mathrm{dn}$ was recorded for control group, while the lowest mean $1.58 \mathrm{dn}$ for infected larvae fed on mulberry leaves sprayed with $1 \%$ black seed extract.

\section{Biological parameters of silkworm larvae treated by some extracts as disinfectants to control artificially infected with $B$. bassiana}

Analysis of data revealed highly significant differences among the silk filament weight means (Table 2). The maximum value $0.318 \mathrm{~g}$ was noticed for control larvae. All tested treatments increased filament weights comparing with filament weights resulting from cocoons spun by larvae treated with infected mulberry leaves by bacterial suspension. 
Table 2 Effect of Mulberry leaves, Black seeds and Basil leaves extracts as disinfectants on silk filament characters of infected silkworm, B. mori larvae with B. thuringiensis

\begin{tabular}{|c|c|c|c|c|}
\hline Extracts & Conc. $^{a}$ & Silk Filament Length $(\mathrm{m})$ & Silk Filament weight (g) & Silk Filament Size (dn) \\
\hline \multirow[t]{3}{*}{ Mulberry Leaves } & $3 \%$ & $1271.50^{\mathrm{a}}$ & $0.300^{\mathrm{a}}$ & $2.123^{a}$ \\
\hline & $2 \%$ & $1147.75^{\mathrm{a}}$ & $0.243^{a}$ & $1.900^{\mathrm{a}}$ \\
\hline & $1 \%$ & $1092.50^{a}$ & $0.223^{\mathrm{a}}$ & $1.830^{\mathrm{a}}$ \\
\hline \multirow[t]{3}{*}{ Black seed } & $3 \%$ & $1214.20^{\mathrm{a}}$ & $0.308^{\mathrm{a}}$ & $2.280^{\mathrm{a}}$ \\
\hline & $2 \%$ & $1145.50^{\mathrm{a}}$ & $0.233^{\mathrm{a}}$ & $1.830^{\mathrm{a}}$ \\
\hline & $1 \%$ & $1154.50^{\mathrm{a}}$ & $0.203^{\mathrm{a}}$ & $1.580^{\mathrm{a}}$ \\
\hline \multirow[t]{3}{*}{ Basil Leaves } & $3 \%$ & $1226.50^{\mathrm{a}}$ & $0.265^{a}$ & $1.943^{\mathrm{a}}$ \\
\hline & $2 \%$ & $1149.75^{\mathrm{a}}$ & $0.260^{\mathrm{a}}$ & $2.033^{\mathrm{a}}$ \\
\hline & $1 \%$ & $1061.75^{\mathrm{a}}$ & $0.238^{\mathrm{a}}$ & $2.020^{\mathrm{a}}$ \\
\hline B. thuringiensis control & & $775.35^{\mathrm{a}}$ & $0.17^{\mathrm{a}}$ & $1.973^{\mathrm{a}}$ \\
\hline Control & & $1089.50^{a}$ & $0.318^{\mathrm{a}}$ & $2.627^{\mathrm{a}}$ \\
\hline$F$ value & & 18.411 & 8.357 & 6.651 \\
\hline $\mathrm{LSD}_{0.05}$ & & 83.230 & 0.040 & 0.320 \\
\hline$P \geq 0.05$ & & $0.0000^{* *}$ & $0.0000^{* *}$ & $0.0000^{* *}$ \\
\hline
\end{tabular}

${ }^{a}$ The tested concentrations of plant extracts (\%)

** denote highly significant differences at $0.05,0.01$ levels of probability

Data tabulated in Table 2 revealed highly significant differences between silk filament size means. The highest silk filament size $2.627 \mathrm{dn}$ was recorded for control group, while the lowest mean $1.58 \mathrm{dn}$ for infected larvae fed on mulberry leaves sprayed with $1 \%$ black seed extract. The statistical analysis showed that there is a high significance among the averages showing that the control is better than the used treatments.

As shown in (Table 3), larval weight means ranged between 4.291 to $3.812 \mathrm{~g}$ for infested silkworm larvae with conidial solution of B. bassiana, treated with plant extract concentrations under study sprayed increased the larval weight compared to 2.937 for infected control. The differences between larval weight means are highly significant.

Infection of mulberry silkworm with conidial solution of B. bassiana increased larval mortality to $27 \%$ comparing to $2 \%$ mortality for control. All plant concentrations under study decreased the larval mortality especially $1 \%$ mulberry leaves and 2, $1 \%$ black seed extracts.

Table 3 Effect of Mulberry leaves, Black seeds and Basil leaves extracts as disinfectants on some biological and cocoon characters of infected Silkworm, B. mori larvae with B. bassiana

\begin{tabular}{|c|c|c|c|c|c|c|c|}
\hline Treatment & Conc. $^{a}$ & Larval weight (g) & Larval Mortality (g) & Pupal weight (g) & Cocoon weight (g) & Cocoon shell wt. (g) & Silk ratio $\%$ \\
\hline \multirow[t]{3}{*}{ Mulberry Leaves } & $3 \%$ & $4.028^{a}$ & $10.67^{a}$ & $1.194^{a}$ & $1.552^{\mathrm{a}}$ & $0.358^{a}$ & $23.058^{\mathrm{a}}$ \\
\hline & $2 \%$ & $4.165^{\mathrm{a}}$ & $9.33^{\mathrm{a}}$ & $1.120^{\mathrm{a}}$ & $1.462^{\mathrm{a}}$ & $0.334^{\mathrm{a}}$ & $22.920^{\mathrm{a}}$ \\
\hline & $1 \%$ & $3.995^{\mathrm{a}}$ & $8.00^{\mathrm{a}}$ & $1.038^{\mathrm{a}}$ & $1.370^{\mathrm{a}}$ & $0.324^{\mathrm{a}}$ & $23.652^{a}$ \\
\hline \multirow[t]{3}{*}{ Black seed } & $3 \%$ & $4.117^{a}$ & $11.33^{\mathrm{a}}$ & $1.408^{\mathrm{a}}$ & $1.776^{\mathrm{a}}$ & $0.362^{a}$ & $21.862^{\mathrm{a}}$ \\
\hline & $2 \%$ & $4.03^{\mathrm{a}}$ & $8.00^{\mathrm{a}}$ & $1.208^{\mathrm{a}}$ & $1.556^{\mathrm{a}}$ & $0.340^{\mathrm{a}}$ & $21.896^{\mathrm{a}}$ \\
\hline & $1 \%$ & $3.812^{\mathrm{a}}$ & $8.66^{\mathrm{a}}$ & $1.150^{\mathrm{a}}$ & $1.464^{\mathrm{a}}$ & $0.310^{\mathrm{a}}$ & $21.228^{a}$ \\
\hline \multirow[t]{3}{*}{ Basil Leaves } & $3 \%$ & $4.291^{a}$ & $11.33^{\mathrm{a}}$ & $1.580^{\mathrm{a}}$ & $1.988^{\mathrm{a}}$ & $0.382^{\mathrm{a}}$ & $19.258^{\mathrm{a}}$ \\
\hline & $2 \%$ & $4.055^{\mathrm{a}}$ & $10.67^{\mathrm{a}}$ & $1.300^{\mathrm{a}}$ & $1.652^{\mathrm{a}}$ & $0.350^{\mathrm{a}}$ & $21.150^{\mathrm{a}}$ \\
\hline & $1 \%$ & $3.924^{\mathrm{a}}$ & $9.33^{\mathrm{a}}$ & $1.128^{\mathrm{a}}$ & $1.394^{\mathrm{a}}$ & $0.314^{a}$ & $22.566^{\mathrm{a}}$ \\
\hline \multicolumn{2}{|c|}{ B. bassiana infected control } & $2.937^{a}$ & $27.00^{\mathrm{a}}$ & $0.980^{a}$ & $1.274^{\mathrm{a}}$ & $0.286^{\mathrm{a}}$ & $22.440^{a}$ \\
\hline \multicolumn{2}{|l|}{ Control } & $3.769^{\mathrm{a}}$ & $2.00^{\mathrm{a}}$ & $1.116^{\mathrm{a}}$ & $1.348^{\mathrm{a}}$ & $0.332^{\mathrm{a}}$ & $24.660^{\mathrm{a}}$ \\
\hline \multicolumn{2}{|l|}{ F value } & 12.664 & 28.081 & 21.115 & 39.134 & 2.769 & 1.175 \\
\hline \multicolumn{2}{|l|}{$\mathrm{LSD}_{0.05}$} & 0.285 & 3.451 & 0.102 & 0.088 & 0.049 & ns \\
\hline \multicolumn{2}{|l|}{$P \geq 0.05$} & $0.0000^{* *}$ & $0.0000^{* *}$ & $0.0000^{* *}$ & $0.000^{* *}$ & $.0073^{* *}$ & 0.3287 \\
\hline
\end{tabular}

a The tested concentrations of plant extracts (\%)

ns and ** denote not significant and highly significant differences at $0.05,0.01$ levels of probability 
Data presented in (Table 3) showed that, B. mori pupal weight recorded the highest means (1.580 and $1.408 \mathrm{~g}$ ), when infected larvae treated $3 \%$ basil leaves and 3\% black seeds extracts. On the contrary, the least pupal weight mean $(0.980 \mathrm{~g})$ was resulted from $B$. bassiana infected control.

\section{Cocoon characters}

Statistical analysis of data in (Table 3) revealed highly significant differences in fresh cocoon weights among different treatment under study. It was found that, spraying infected silkworm, B. mori larvae with mulberry leaves, basil leaves and black seed extracts at 3, 2 and 1\% concentrations increased fresh cocoon weights as compared to control. On the other hand, B. bassiana infected control recorded the least cocoon weight.

Regarding cocoon shell weight, infection of mulberry silkworm with conidial solution of $B$. bassiana decreased cocoon shell weight to $0.286 \mathrm{~g}$ as compared to $0.332 \mathrm{~g}$ for control. Spraying infected larvae by 3 and $2 \%$ of mulberry leaves, black seed and basil leaves extracts increased cocoon shell weight (Table 3). Analysis of data, revealed highly significant differences among means. With respect to silk ratio, analysis of data in (Table 3) revealed that, there no differences among means are non-significant. Control larvae occupied the first rank in silk ratio recording $24.660 \%$, followed by treating infected larvae with all concentrations of mulberry leaves extract.

\section{Silk filament characters}

Concerning silk filament length, it was found that infection of $B$ mori larvae with $B$. bassiana conidial solution decreased silk filament length to $691.50 \mathrm{~m}$ comparing to $1089.50 \mathrm{~m}$ for control. Treatment of infected larvae with investigated plant extracts as disinfectants at 3 and $2 \%$ increased silk filament length as shown in Table 4. Application of all tested concentrations of mulberry leaves, black seeds and basil leaves extracts on infected $B$ mori larvae with $B$. bassiana conidial solution increased the silk filament weight as compared to infected not treated group (Table 4). With regard of silk filament size, it was observed that control group gave the highest value $(2.627 \mathrm{dn})$, meanwhile, 3\% mulberry leaves extract showed the least value $(1.755 \mathrm{dn})$. Other tested concentrations gave intermediate values. Analysis of data in Table 4, revealed highly significant differences among the means for the above mentioned silk filament traits.

\section{Discussion}

Disinfection and maintenance of hygiene during rearing are the essential factors for preventing of silkworm diseases. Disease incidence occur in all larval instars but more commonly in the 4 th and $5^{\text {th }}$ instars and cause
Table 4 Effect of Mulberry leaves, Black seed and Basil leaves extracts as disinfectants on silk filament characters of infected Silkworm, B. mori larvae with B. bassiana

\begin{tabular}{lllll}
\hline Extracts & Conc. $^{\mathrm{a}}$ & $\begin{array}{l}\text { Silk Length } \\
(\mathrm{m})\end{array}$ & $\begin{array}{l}\text { Silk weight } \\
(\mathrm{g})\end{array}$ & $\begin{array}{l}\text { Silk size } \\
(\mathrm{dn})\end{array}$ \\
\hline Mulberry Leaves & $3 \%$ & $1153.00^{\mathrm{a}}$ & $0.225^{\mathrm{a}}$ & $1.755^{\mathrm{a}}$ \\
& $2 \%$ & $1103.75^{\mathrm{a}}$ & $0.223^{\mathrm{a}}$ & $1.823^{\mathrm{a}}$ \\
& $1 \%$ & $993.750^{\mathrm{a}}$ & $0.203^{\mathrm{a}}$ & $1.840^{\mathrm{a}}$ \\
Black seed & $3 \%$ & $1286.40^{\mathrm{a}}$ & $0.290^{\mathrm{a}}$ & $2.070^{\mathrm{a}}$ \\
& $2 \%$ & $1158.45^{\mathrm{a}}$ & $0.253^{\mathrm{a}}$ & $1.963^{\mathrm{a}}$ \\
& $1 \%$ & $1012.25 \mathrm{~d}^{\mathrm{a}}$ & $0.240^{\mathrm{a}}$ & $2.138^{\mathrm{a}}$ \\
Basil Leaves & $3 \%$ & $1106.40^{\mathrm{a}}$ & $0.315^{\mathrm{a}}$ & $2.550^{\mathrm{a}}$ \\
& $2 \%$ & $1085.00^{\mathrm{a}}$ & $0.275^{\mathrm{a}}$ & $2.273^{\mathrm{a}}$ \\
& $1 \%$ & $958.40^{\mathrm{a}}$ & $0.280^{\mathrm{a}}$ & $2.430^{\mathrm{a}}$ \\
B. bassiana infected control & $691.50^{\mathrm{a}}$ & $0.160^{\mathrm{a}}$ & $2.080^{\mathrm{a}}$ \\
Control & & $1089.50^{\mathrm{a}}$ & $0.318^{\mathrm{a}}$ & $2.627^{\mathrm{a}}$ \\
F value & & 26.028 & 7.804 & 5.491 \\
LSD 0.05 & 98.2 & 0.05 & 0.34 \\
P $\geq 0.05$ & & $0.0000^{* *}$ & $0.000^{* *}$ & $0.000^{* *}$
\end{tabular}

${ }^{a}$ The tested concentrations of plant extracts (\%)

** denote highly significant differences at $0.05,0.01$ levels of probability

cocoon crop losses (Khurad et al. 2004). The incidence of diseases at the time of silkworm rearing severely decreased the production of silk. Bacillus has been identified as one of the most important pathogenic organism involve in flacherie (Steinhuaus 1949).

According to the obtained results, using the plant extracts to the infected mulberry silkworm, $B$. mori with bacterial suspension (B. thuringnsis) indirectly increased larval weight and decreased the larval mortality of both 4th and 5th instars because of eliminating the chance of larval infection. Our results indicated that, basil leaves and black seed extracts proved to give the highest results for biological and cocoon characters. The antimicrobial activity of $O$. basilicum (basil) is due to its phenolic acids and aromatic compounds Gutierrez et al. (2008). Lachowiez et al. (1998) cleared that, the essential oils from Ocimum species were predominantly associated with the main constituent's linalool and methyl chavicolwhich responsible for antibactericidal effect on gram-positive and gram-negative bacteria. So it can be used as disinfectant for infected silkworm and to increase the cocoon production. The same results were obtained by Hassan and Saad (2012) who found that, larval weight increased significantly when treated with germ wheat oil.

The obtained results of the investigated plant extracts showed that, plant extracts at different concentrations showed not only antibacterial activity against the bacteria (B. thuriengiensis) that infected the mulberry silkworm but also showed improvement of the economic traits. Herbal extracts show antimicrobial activity against some 
pathogenic microorganisms including Gram positive bacteria such as S. aureus and B. subtilis and Gram-negative bacteria such as E. coli (Whitt and Salyers 2002; Sivakumar et al. 2012). Similar observation was indicated by Mohanta et al. (2013) who stated that, ethanol extracts of C. zeylenicum, C. longa, Z. officinale plants showed a strong antibacterial activity against pathogens isolated from diseased silkworm with bacterial Flacherie.

Sujatha and Sampath (2015) stated that, clove oil was active against Bacillus cereus and Proteus vulgaris and could be used for controlling the flacherie disease, which infected mulberry silkworm, B. mori. It found that, clove oil increased significantly cocoon parameters of silkworm as compared to control. Similarly, chloroform leaf extract of Aeglemarmelosandbark extracts of Thujaorientalis were affecting in managing $B$. thuringiensisand $S$. aureusinfecting B. mori (Manimegalai et al. 2010). These results are in partial accordance with Shyam et al. (2017) who treated infected silkworm with the Trichosanthes cucumerina seeds and leaves extract and found that, seed extract of $T$. cucumerinat $\mathrm{T} 1(\mathrm{~T} 1=1: 1=$ plant: water) recorded maximum cocoon weight, pupal weight, shell weight, silk ratio percentage and filament length. Moreover, El-Sayed (1999) stated that, the mixture of honey and black seeds increased silk production and the number of deposited eggs/female and gave heaviest weight of larvae, pupae and increased the total protein of the silk gland .

Obtained results indicated that, all concentrations of the plants under study enhanced the silk filament length, weight and size in comparing with silk filaments resulting from cocoons spun by larvae treated with infected mulberry leaves with bacterial suspension. Similar results were reported by Elyamani and Zannoon (2017) who studied the effect of fortification of mulberry leaves with Cichorium intybus L. aqueous extract on some biological and technological characters of silkworm, B. mori and found that, all tested concentrations increased silk filament length as compared to control.

Muscardine infection was reported higher during winter season, less during rainy season and it may be due to low temperature with high humidity in silkworm rearing environment, which work as a pre-requisite for outbreak of the fungal disease and efficacy of the bed disinfectants (Chandrasekharan 2009). In Egypt, the incidence of muscardine infection is very rare because most silkworm rearing occur during spring and autumn seasons, where the weather is moderate in temperature and humidity.

Obtained results indicated that, artificial infection of mulberry silkworm with conidial solution of B. bassiana increased larval mortality and decreased larval weight of silkworm, B. mori. The cocoons spun by diseased larvae with $B$. bassiana became weak and have light weight and silk ratio, also the reeled silk filaments were short in lengths and had small sizes and weights.

Study the efficacy of petroleum-ether extracts of $M$. alba, O. basilicum leaves and N. sativa seeds as disinfectants against $B$. bassiana proved that, those plant extracts were effective and caused improvement in most traits under study. Similar results were recorded by Rehab et al (2016) who obtained highest larval weight and Cocoon weight after application of LC (mix of Lawson iainermis and Curcuma longa powders). Cocooning percentage was significantly high in FL (Formaldehyde and lime powder 0.25: 0.75 ) and LC treatments as compared to inoculated control group (immersed in fungal spores solution). These results were agree with the finding of Padma and Ramani (2014) who stated that, ethanolic leaf extract of $O$. sanctum was effective in controlling white muscardine disease caused by $B$. bassiana and increased the cocoon weight, pupal weight, shell weight and shell ratio. Recently several reports have come on antimicrobial activity of plant extracts against bacteria and fungi (Mohanan et al. 2007; Chavan et al. 2013). Application of Ankush vijetha green and Slaked lime powder combination as per recommended schedule leads to low muscardine incidence during winter season and increased single cocoon weight, shell weight, pupal weight, shell percentage, filament length and cocoon yield (Shashidhar et al. 2018). Moreover, Soumya (2011) proved that, the two botanicals (Eucalyptus hybrid and Moriga olifera) when dusted at $100 \%$ every day on silkworm inoculated with stock solution of fungal spore suspension enhanced larval weight, cocoon weight, shell weight, pupal weight, shell ratio, silk filament length, denier and reduced larval mortality compared to other treatments.

Most of the biological activity of Nigella sativa seeds showed by the oil constituents like, Thymoquinone (ElTahir and Bakeet 2006). The antifungal activity of Thymoquinone from Nigella sativa had evaluated by the standard agar plate method (Aljabre et al. 2005).

\section{Conclusions}

Tested concentrations of Morus alba, Ocimum basilicum leaves extracts and Nigella sativa seeds extract have suppressed the bacterial and fungal disease spread when used three times through both 4th and 5th larval instars. Moreover, the biological characters and technological traits enhanced indirectly by using of these extracts, so it can be used in sericulture for improving cocoon crop crop production, i.e., quality and quantity.

\section{Abbreviations}

Dn: Denier (silk filament size measuring unit); FL: Formaldehyde and lime powder 0.25: 0.75; LC: Mix of Lawson iainermis and Curcuma longa powders Juvenile hormones; $\mathrm{NaCl}$ : Sodium chloride 


\section{Acknowledgements}

The authors would like to acknowledge sericulture department, Plant proterction Institute, ARC, Egypt for providing silkworm hybrid.

\section{Authors' contributions}

MSIS carried out the breeding and physiological studies, participated in the design of the study, performed the statistical analysis and helped to revise the manuscript. EMYE participated in the sequence alignment and drafted the manuscript, and helped to revise the manuscript. WMMH conceived of the study, and participated in its design and coordination and helped to draft the manuscript. All authors read and approved the final manuscript.

\section{Funding}

No funding personal Research.

\section{Availability of data and materials}

The datasets used and/or analyzed during the current study are available from the corresponding author on reasonable request.

\section{Ethics approval and consent to participate}

Not applicable.

\section{Consent for publication}

Not applicable.

\section{Competing interests}

The authors declare that they have no competing interests.

\section{Author details}

${ }^{1}$ Plant Protection Research Institute, Agricultural Research Center, Dokki 12622, Egypt. 'Department of Plant Protection, Faculty of Agriculture,

Zagazig University, Zagazig 44511, Egypt.

\section{Received: 30 April 2019 Accepted: 22 October 2019}

Published online: 04 December 2019

\section{References}

Ahmed A, Husain A, Mujeeb M, Alam K, Najmi Abul, Siddique, N (2013) A review on therapeutic potential of Nigella sativa: a miracle herb. Asian Pac J Trop Biomed 3(5): 337-352

Aljabre SHM, Randhawa MA, Akhtar N, Alakloby OM, Alqurashi AM, Aldossary A (2005) Antidermatophyte activity of ether extract of Nigella sativa and its active principle, thymoquinone. J Ethnopharmacol 101(1-3):116-119

Aneja KR (2003) Experiments in microbiology, plant pathology and biotechnology. New age international (P) limited publishers, 4th edn, p 376

Bushra BNR, Ganga DT (2003) Antibacterial activity of selected sea weeds from Kovalam south west coast of India. Asian J of Microbiol Biotech Env Sc 5(3): 319-322

Chandrasekharan K (2009) Studies on the management of white muscardine disease in the silkworm, B. mori L. Ph.D. Thesis, University of Mysore, Mysore, p 210

Chavan JA, Patil SJ, Bhawane GP (2013) Effect on the cocoon character of B. bassiana infection and subsequent treatment of ethanolic plant extracts on Vth instar larvae of B. mori L. J Sci Technol 21(1):45-52

Cockerill I, Franklin R, Wikler MA, Alder J (2012) Methods for dilution antimicrobial susceptibility tests for bacteria that grow aerobically; approved standard, Clinical and laboratory standers institute. M02-A9 32(2), 9th edn, pp 1-12

CoStat V. 6.311 (2005) Copyright(c) 1998-2005 CoHort software 798 lighthouse Ave. PMB 320, Monterey, CA, 93940, USA

Dandin S B (2014) Mulberry (Morus spp.)- a unique gift of nature to mankind. The proceeding of the $23^{\text {rd }}$ international congress on Sericulure \& Silk Industry, Bangalore-India

Das GMR (1950) Diseases of silkworm monograph on cottage industries. No1, Govt. India press Calcutta 25

Desai SD, Shaik HS, Kusal KD, Haseena S (2015) Phytochemical analysis of Nigella sativa and it's antidiabetic effect. J Pharm Sci Res 7(8):527-532

El-Beshbishy HA, Singab AN, Sinkkonen J, Pihlaja K (2006) Hypolipidemic and antioxidant effects of $M$. alba L. (Egyptian mulberry) root bark fractions supplementation in cholesterol-fed rats. Life Sci 78:2724-2733

El-Sayed NAA (1999) Evaluation of six mixtures of food additives on some biophysiological and reproductivity parameters of the mulberry silkworm $B$. mori L. Monofia J Agric Res 24(6):1971-1986
El-Tahir KEH, Bakeet DM (2006) The black seed Nigella sativa L. a min for multi cure: a plea for urgent clinical evaluation of its volatile oil. J Taibah Uni Med Sci 1(1):1-19

Elyamani EM, Zannoon AA (2017) Effect of Cichorium intybus aqueous extract as nutritional additives on some biological aspects and silk production of mulberry silkworm B. mori L, The twelfth inter environmental Conf Facuulty of science Zagazig Univ, pp 353-367

Gutierrez B, Ryan C, Bourke P (2008) The antimicrobial efficacy of plant essential oil combinations and interactions with food ingredients. Int J Food Microbiol 124:91-97

Harborne JB (1984) Phytochemical methods, 2nd edn. Edited by Chapman \& Hall, London, pp 150-160

Hassan EM (2015) Effect of Dexatrol and peppermint oil as disinfectants on some biochemical characters of infected silkworm B. mori. J Entomol 12(1):12-20

Hassan EM, Saad MSI (2012) Biological and technological effects of germ wheat oil as a nutritional additive on silkworm B. mori growth. Egypt J Agric Res 90(2):527-535

Kartal M (2007) Intellectual property protection in the natural product drug discovery, traditional herbal medicine and herbal medicinal products. Phytother Res 21:113-119

Karthikairaj K, Prasannakumar K, Isaiarasu L (2013) Use of plant extracts for the control of flacherie disease in silkworm, B. mori L. (Lepidoptera: Bombicidae). Int J Microbiol Res 4(2):158-161

Kath RK, Gupta RK (2006) Antioxidant activity of hydro alcoholic leaf extract of Ocimum sanctum in animal models of peptic ulcer. Indian J Physiol Pharmacol 50:391-396

Khurad AM, Mahulikar A, Rathod MK, Rai MM, Kanginakurdu S, Nagaraju J (2004) Vertical transmission of nuclear polyhedrovirus in the silkworm, B. mori L. J Invertebr Pathol 87:8-15

Krishnaswami S (1978) New technology of silkworm rearing Central sericulture researches and training institute. Mysore Bull 2:1-10

Lachowiez KJ, Jones GP, Briggs DR, Bienvenu FE, Wan J, Wilcock CMJ (1998) The synergistic preservative effects of the essential oils of sweet basil against acid tolerant food microflora. Lett Appl Microbiol 26:209-214

Linday ME (1962) Practical introduction to microbiology. London E and F N Spon Ltd, UK, p 177

Mahmoud SM (2016) Silk agriculture and industry. Noor publishing, GmbH, Nordersted / Germany, pp 1-288

Manimegalai S, Adhithya R, Vellaikumar S, Paramasivam M, Chandrasekaran S (2010) Separation and characterization of antibacterial compounds from Aegle marmelos Correa and Thuja orientalis L. against silkworm pathogens. Int J Genet Eng Biotechnol 1(3):177-186

Meyling NV (2007) Method for isolation of entomopathogenic fungi from the soil environment 18 pages

Meyling NV, Eilenberg J (2006) Isolation and characterization of B. bassiana isolates from phylloplanes of hedgerow vegetation. Mycol Res 110:188-195

Mohanan NM, Guta SK, Mitra P (2007) Antimicotic activity of Allium sativum against $B$. bassiana, pathogenic fungus of white muscardine disease in silkworm, B. mori L. Int J Ind Entomol 14(2):81-85

Mohanta MK, Saha AK, Saleh DKMA, Hasan MA (2013) Bioefficacy of some plant extracts against pathogenic bacteria isolated from diseased silkworm larvae. Rajshahi Univ Zool Soc 32:09-14

Morsi N (2000) Antimicrobial effect of crude extracts of Nigella sativa on multiple antibiotics-resistants bacteria. J Acta Microbiol 49:63-74

Omidiran MO, Baiyewu RA, Ademola IT, Fakorede OC, Toyinbo EO, Adewumi OJ, Adekunle EA (2012) Phytochimical analysis, nutritional composition and antimicrobial activities of white mulberry (M. alba). Pak J Nutr 11(5): 456-460

Padma VDP, Ramani B (2014) Antifungal effect of Ocimum sanctum L. against white muscardine disease of silkworm, B. mori L. J Biopesticides 7(2):204-208

Pereira P, Huerta B, Borge C, Astorga R, Romero R, Perea A (2004) Antimicrobial activity of five essential oils against origin strains of the Enterobacteriaceae family. Acta Pathol Microbiol Immunol Scand 113(1):1-6

Prasad MP, Jayalakshmi K, Rindhe GG (2012) Antibacterial activity of Ocimumspecies and their phytochemical and antioxidant potential. Int J Microbiol Res 4(8):302-307

Ramesh B, Satkopan VN (2010) Antioxdidant activities of hydroalcoholic extract of Ocimum sanctum against cadmuim induced toxicity in rats. Indian J Clin Biochem 25(3):307-310

Shaaban FO (1997) Studies on the silkworm, Bombyx mori L. m.Sc. Thesis, Faculty of Agriculture Zagazig University, p 134 
Shashidhar KR, Thulasiram K, Noorulla H (2018) Effectiveness of bed disinfectants on silkworm diseases and cocoon yield under tropical conditions of Kolar district, Karnataka. J Pharmacognosy Phytochemistry 7(5):2720-2724

Shyam SR, Sampath A, Sathish J, Sujatha K (2017) Effect of leaf and seed extracts of $T$. cucumerina $L$ on antibacterial activity and economic traits of mulberry silkworm, B. mori L. J Entomol Zool Stud 5(2):889-894

Sivakumar T, Shankar T, Vijayabaskar P, Geetha G (2012) Efficacy of Couroupita guianensis against selected human pathogens. Adv Biol Res 6(2):59-63

Snedecor GW, Cochran WG (1982) Statistical methods. lowa State University Press, Amer lowa

Soumya B R (2011) Use of botanicals as bed disinfectant against white muscardine disease of silkworm, B. mori L. M. Sc University of agricultural sciences, Bengaluru

Steinhuaus EA (1949) Principles of insect pathology. Mc Graw-Hill, New York Sujatha K, Sampath A (2015) Clove oil for the control of flacherie disease and its effect on economic traits of silkworm, B. mori. Int J Pharm Bio Sci 6:1311-1323

Tanaka Y (1964) Sericology central silk board, Bombay (95). B Megdoot Marine Drive:216-220

Whitt D, Salyers A (2002) Bacterial pathogenesis: a molecular approach, 2nd edn. ASM press, USA

Yeo H, Pell JK, Alderson PG, Clark SJ, Pye BJ (2003) Laboratory evaluation of temperature effects on the germination and growth of entomopathogenic fungi and their pathogenicity to two aphid species. Pest Manag Sci 59:156-165 Yogisha S, Raveesha KA (2009) In-vitro antibacterial effect of selected medicinal plant extracts. J Nat Prod 2:64-69

Zannoon AA, Shadia MO (1994) Efficiency of certain natural materials as mountages for mulberry silkworm, Bombyx mori L. Egypt J Appl Sci 9(8):691-696

\section{Publisher's Note}

Springer Nature remains neutral with regard to jurisdictional claims in published maps and institutional affiliations.

\section{Submit your manuscript to a SpringerOpen ${ }^{\circ}$ journal and benefit from:}

- Convenient online submission

- Rigorous peer review

- Open access: articles freely available online

- High visibility within the field

- Retaining the copyright to your article

Submit your next manuscript at $\boldsymbol{\nabla}$ springeropen.com 